\title{
Nitrate and potassium movement in a sandy loam soil cultivated with fertigated grapevine (Vitis vinifera/L.) in the Brazilian semiarid
}

\author{
Alexsandro Oliveira da Silva ${ }^{1}$, Luis Henrique Bassoi ${ }^{2}$, Davi José Silva ${ }^{3}$ \\ Abstract - Fertigation can increase the efficiency of fertilizer application and facilitate the \\ nutritional management of a crop. Thus, nitrate and potassium movements in a sandy loam soil \\ were evaluated as function of fertilizer doses during three growing seasons of the grapevine $\mathrm{cv}$. \\ Syrah grafted on Paulsen 1103 rootstock (June to October 2013, February to June 2014, and \\ August to November 2014) in Petrolina, state of Pernambuco, Brazil. Five doses of N $(0,15$, \\ 30,60 and $\left.120 \mathrm{~kg} \mathrm{ha}^{-1}\right)$ and five doses of $\mathrm{K}_{2} \mathrm{O}\left(0,15,30,60\right.$ and $\left.120 \mathrm{~kg} \mathrm{ha}^{-1}\right)$ were combined in a \\ fractional $5^{2}$ factorial design, totaling 13 combinations, in a randomized blocks experiment with \\ four replications. The concentrations of nitrate and potassium in the soil solution were determined. \\ Samples were collected by porous cup extractors installed at 0.4 and $0.6 \mathrm{~m}$ depths. The movement \\ of these ions was obtained by the product between their concentration in the soil solution and \\ the soil water flux density. The increase in nitrogen fertilization promoted a greater movement of \\ $\mathrm{NO}_{3}^{-}\left(62.2 \mathrm{~kg} \mathrm{ha}^{-1}\right)$ in the soil. The movement of $\mathrm{K}^{+}$was also observed in two growing seasons . \\ Index terms: Irrigation management, porous cup extractor, Soil solution.

\section{Movimento de nitrato e potássio em solo arenoso cultivado com videira (Vitis vinifera L.) fertirrigada no Semiárido}

Corresponding author: alexsandro@ufc.br

Received: November 09, 2017. Accepted: May 17, 2018.

Copyright: All the contents of this journal, except where otherwise noted, is licensed under a Creative Commons Attribution License.
Resumo - A prática da fertirrigação pode aumentar a eficiência de aplicação de fertilizantes e facilitar o manejo nutricional de uma cultura agrícola. Assim, os movimentos de nitrato e de potássio em solo de textura francoarenosa foram avaliados em função da dose de fertilizantes, durante três ciclos de produção da videira de vinho cv. Syrah sobre o porta-enxerto Paulsen 1103 (junho a outubro de 2013, fevereiro a junho de 2014 e agosto a novembro 2014), em Petrolina, Pernambuco. Cinco doses de $\mathrm{N}\left(0 ; 15 ; 30 ; 60\right.$ e $\left.120 \mathrm{~kg} \mathrm{ha}^{-1}\right)$ e cinco doses de $\mathrm{K}_{2} \mathrm{O}\left(0 ; 15 ; 30 ; 60\right.$ e $\left.120 \mathrm{~kg} \mathrm{ha}^{-1}\right)$ foram combinadas em um esquema fatorial $5^{2}$ fracionado, em um total de 13 combinações, e com disposição dos tratamentos em blocos casualizados, com quatro repetições. A concentração de nitrato e de potássio foi determinada na solução do solo, que foi coletada por meio de extratores de cápsulas porosas instalados a 0,4 e $0,6 \mathrm{~m}$ de profundidade. O movimento desses íons foi obtido pelo produto entre a concentração dos mesmos na solução do solo e a densidade de fluxo de água no solo. $\mathrm{O}$ aumento da adubação nitrogenada promoveu maior movimento de $\mathrm{NO}_{3}^{-}\left(62,2 \mathrm{~kg} \mathrm{ha}^{-1}\right)$ no solo. O movimento de $\mathrm{K}^{+}$também foi observado em dois ciclos de produção.

Termos para indexação: Manejo da irrigação. Extrator de cápsulas porosas. Solução do solo. 


\section{Introduction}

The adoption of localized irrigation systems makes fertigation feasible. It contributes to a greater efficiency in the application of fertilizers and a greater ease in the nutritional management of crops (SILVA et al., 2016; SHARMA et al., 2014). Currently, the use of fertigation is a common practice in grapevine cultivation (Vitis vinifera L.) in the Lower Middle São Francisco river valley, where fertilizers containing nitrogen $(\mathrm{N})$ and potassium $(\mathrm{K})$ are frequently used due to a need for these nutrients by crops (ROCHA et al., 2015; SILVA et al., 2014) mainly during phenological phases such as flowering and grape ripening.

The production of vine is related to different managements, such as an efficient use of irrigation (BASSOI et al., 2015) and fertilizers (ALBUQUERQUE et al., 2013). Therefore, a correct management of water and fertilizers is necessary to avoid increases in production costs and minimize damages to the environment. Among the problems that arise from an excessive application of fertilizers, we can mention contamination of water tables, by which elements are leached to depths below the root system, and may reach water sources and pollute the environment (BORTOLOTTO et al. 2013). Among the fertilizers that may cause pollution as a consequence of an inadequate management, we can highlight $\mathrm{N}$ fertilizers, with an emphasis on the nitrate ion $\left(\mathrm{NO}_{3}^{-}\right)$and its action in the contamination of groundwater (ANDRADE et al., 2016), and potassium fertilizers, which may raise the levels of $\mathrm{K}^{+}$in the soil to levels above those required for crops when applied excessively (SILVA et al., 2014). In semi-arid regions, the contamination of groundwater may happen even faster, since the soil of such regions are shallow and groundwater is close to the surface (BADR et al., 2016). This problem may further aggravate the hydric situation in such regions, as there are few good water sources.

The main losses of $\mathrm{N}$ are caused by denitrification, volatilization and leaching. The latter is responsible for $72 \%$ of total $\mathrm{N}$ losses in the conventional fertilizer (QUAGGIO et al., 2014). The movement of $\mathrm{N}$ in the soil occurs by convection processes of the soil solution, also called mass flows, and by molecular or ionic diffusion due to concentration gradients. Nitrogen movement occurs commonly in the $\mathrm{NO}_{3}^{-}$form, and may be intensified by the excess of water resulting from irrigation systems (MENDES et al., 2015) and by successive $\mathrm{N}$ fertilizations (BORTOLOTTO et al., 2013).

The movement of $\mathrm{K}$ in the soil depends on the soil type. In most cases, it moves with limitations (SHARMA et al., 2014). In soils with a low cation exchange capacity, this nutrient can be leached. However, when adequate fertilizer doses are applied, leaching losses are extremely low for most conditions. According to Sharma et al. (2014), $\mathrm{K}$ can move in the soil profile when there is a concentration of this element near the emitters of the irrigation system, thus increasing concentrations of this nutrient near the root system located within the wet bulb.

This study aims to evaluate the movement of $\mathrm{NO}_{3}^{-}$ and $\mathrm{K}^{+}$in a soil cultivated with fertigated wine vine in Petrolina, in the Brazilian semiarid region.

\section{Materials and methods}

\section{Experimental characterization}

The experiment was conducted at the Experimental Field of Bebedouro, which belongs to Embrapa Semiárido, in Petrolina, state of Pernambuco, Brazil, located at 0908'08.09" S, 40 $10^{\circ} 33.6^{\prime \prime} \mathrm{W}$ and altitude of $373 \mathrm{~m}$. The climatic classification according to Köppen is BSWh, semiarid tropical. Grapevine (Vitis vinifera L.), cultivar Syrah, was grafted into Paulsen 1103 rootstocks. The planting was carried out on April 30, 2009, using a spacing of $1 \mathrm{~m}$ between plants and $3 \mathrm{~m}$ between rows in a Argissolo Vermelho-Amarelo Eutrófico plintossólico (Santos et al., 2013) which corresponds a Typic Plinthustalf (Soil Survey Staff, 2014). The period of formation of trellised vines occurred until April 2010, when the first pruning was performed. Three prunings were performed on June 17, 2013, February 7, 2014, and August 6, 2014, with the respective harvests performed on October 8, 2013, June 9, 2014, and November 25, 2014, resulting in growing seasons with durations of 113,122 and 111 days, respectively.

Previously to the beginning of the experiment, 36 soil samples were collected from the layers $0-0.20,0.20$ 0.40 and $0.40-0.60 \mathrm{~m}$ in plant rows. The samples were analyzed by the Laboratory of Soils and Leaf Analysis of Embrapa Semiárido to determine the physical (Table 1) and chemical (Table 2) attributes of the soil according to the methodologies described by Donagema et al. (2011).

The treatments comprised five nitrogen doses $(0$, $15,30,60$ and $\left.120 \mathrm{~kg} \mathrm{ha}^{-1}\right)$ and five $\mathrm{K}_{2} \mathrm{O}$ doses $(0.15,30$, 60 and $\left.120 \mathrm{~kg} \mathrm{ha}^{-1}\right)$. These treatments were combined in a fractionated $5^{2}$ factorial design (LITTEL and MOTT, 1975), totaling 13 combinations. The experiment used randomized blocks with four replications. The experimental unit consisted of 17 plants.

The drip irrigation system was used. Each experimental plot had $17 \mathrm{~m}$ long side rows (polyethylene hoses) controlled by a shut off valve to open at each fertigation event. The suction system consisted of a $6 \mathrm{~m}$ long pipe connected to a water reservoir, a water pump with a flow rate of $15 \mathrm{~m}^{3} \mathrm{~h}^{-1}$, a disc filter, an injection pump and a $60 \mathrm{~L}$ reservoir for fertilizer solution. Fertigation was performed once a week by an injection pump with a capacity of $300 \mathrm{~L} \mathrm{~h}^{-1}$. The fertilizers were potassium sulphate $\left(50 \%\right.$ of $\left.\mathrm{K}_{2} \mathrm{O}\right)$, potassium chloride $\left(60 \%\right.$ of $\left.\mathrm{K}_{2} \mathrm{O}\right)$, potassium nitrate $\left(12 \%\right.$ of $\mathrm{N}$ and $45 \%$ of $\left.\mathrm{K}_{2} \mathrm{O}\right)$ and urea $(46 \%$ of $\mathrm{N})$. The accompanying ions were balanced by 
complementary fertilization.

Irrigation management was performed based on the estimation of crop evapotranspiration (ETc). For this, the reference evapotranspiration $\left(\mathrm{ETo}, \mathrm{mm} \mathrm{day}^{-1}\right)$ was estimated by the Penmam-Monteith FAO method (ALVES et al., 2017) using data collected by an automatic weather station located $60 \mathrm{~m}$ from the experimental area. The crop coefficients $(\mathrm{kc})$ for wine vine $\mathrm{cv}$. Syrah were obtained by Bassoi et al. (2007) in the same location of the experiment.

To monitoring soil moisture $\left(\theta, \mathrm{m}^{3} \mathrm{~m}^{-3}\right)$, six sets of tensiometers were installed at the experimental area. Each contained one instrument at the depths $0.20 \mathrm{~m}, 0.40$ $\mathrm{m}$ and $0.60 \mathrm{~m}$. The soil water matric potential $\left(\phi_{\mathrm{m}}, \mathrm{kPa}\right)$ was determined by a digital punction tensiometer and tension reader. Using a soil water retention curve, the corresponding soil moisture value was determined.

The soil water retention curve was determined at the Laboratory of Soil and Leaf Analysis at Embrapa Semiárido using the centrifuge method (ASSIS et al., 2015) in deformed soil samples collected by an auger at the depths $0-0.20 \mathrm{~m}, 0.20-0.40 \mathrm{~m}$ and $0.40-0.60 \mathrm{~m}$. Afterwards, the parameters of the soil water retention curve equation (Table 3 ) were obtained using the software SWRC - Soil Water Retention Curve (DOURADO NETO et al., 2000).

\section{Soil water balance}

During the three growing seasons of grapevine cv. Syrah, the soil water balance was estimated from the pruning until harvesting according to equation 1 :

$$
R n+I \pm D / A \pm \Delta h \pm R o-E T c=0
$$

Where ETc is crop evapotranspiration ( $\mathrm{mm}), \mathrm{Rn}$ is rainfall $(\mathrm{mm}), \mathrm{I}$ is the irrigation $(\mathrm{mm}), \Delta \mathrm{h}$ is the variation in soil water storage $(\mathrm{mm}), \mathrm{D} / \mathrm{A}$ is the deep drainage descending flow or capillary rise - ascending flow ( $\mathrm{mm})$, and Ro is the soil surface flow - runoff ( $\mathrm{mm}$ ).

Soil water storage $(\mathrm{h}, \mathrm{mm})$ was determined by integration of soil moisture for each soil layer of interest using equation 2 .

$$
\Delta h=\int_{0}^{L} \theta(z) d z \cong\left[1,5 \theta\left(z_{1}\right)+\sum \theta\left(z_{i}\right)+0,5\left(z_{n}\right)\right] \Delta Z
$$

Where $\theta\left(\mathrm{z}_{1}\right)$ is the moisture of the first layer $\left(\mathrm{m}^{3}\right.$ $\left.\mathrm{m}^{-3}\right), \theta\left(\mathrm{z}_{\mathrm{i}}\right)$ is the moisture of intermediate layers $\left(\mathrm{m}^{3} \mathrm{~m}^{-3}\right)$, $\theta\left(\mathrm{z}_{\mathrm{n}}\right)$ is the moisture of the last layer $\left(\mathrm{m}^{3} \mathrm{~m}^{-3}\right), d_{z}$ is the variation of moisture in the soil layer of interest $\left(\mathrm{m}^{3} \mathrm{~m}^{-3}\right)$, and $\Delta z$ is the thickness of the soil layer $(\mathrm{mm})$.

The variation of soil water storage was calculated during the periods studied by the following equation 3 :

$$
\Delta h=h_{f}-h_{i}
$$

Where $\Delta \mathrm{h}$ is the variation of soil water storage $(\mathrm{mm}), \mathrm{H}_{\mathrm{f}}$ is the mean storage at final time $(\mathrm{mm})$, and $\mathrm{h}_{\mathrm{i}}$ is the mean storage at initial time $(\mathrm{mm})$.

For the determination of the unsaturated soil hydraulic conductivity (CONCEIÇÃO, 2014) by the instantaneous field profile method, a $10 \mathrm{~m}^{2}$ plot inside the experimental area was used where tensiometers were installed at the depths $0.20,0.40$ and $0.60 \mathrm{~m}$. The soil profile was saturated with water using a hose to moisten the upper soil layer $(0.60 \mathrm{~m})$. The readings of tensiometers, which were close to zero, indicated saturation of the soil layer of interest. Subsequently, the plot was covered with a plastic cover to prevent any water flow through the soil surface or water evaporation from the soil. The time of the cover installation was considered the time zero $(t=0)$ of soil water redistribution. Therefore, tensiometer readings began and were taken until the drainage became practically null (20 days), which was verified by the stability of readings of soil water tension.

The hydraulic conductivity as function of matric potential $\left(\phi_{\mathrm{m}}\right)$ was determined by the equation (4) using water content data in the profile obtained from tensiometer readings and retention curves determined at the same depths:

$$
\left.K(\theta)\right|_{z}=\frac{\int_{0}^{z} \frac{\partial}{\partial} d z}{\left.\frac{\partial \phi_{t}}{\partial z}\right|_{z}}=\frac{\frac{\partial h_{z}}{\partial t}}{\left.\frac{\partial \phi_{t}}{\partial z}\right|_{z}}
$$

Where $\mathrm{h}_{z}\left(\mathrm{~m}^{3} \mathrm{~m}^{-2}\right)$ is soil water storage between the surface $(z=0)$ and the depth $z$, tis redistribution time, and $\phi_{t}$ is the total soil water potential.

As the values of the function $K(\theta)$ present an exponential relation with moisture, the equation (5) was expressed by:

$$
K(\theta)=K_{o} e^{\gamma\left(\theta-\theta_{o}\right)}
$$

Where $K(\theta)$ is the unsaturated soil hydraulic conductivity $\left(\mathrm{mm} \mathrm{day}^{-1}\right)$, Ko is the saturated soil hydraulic conductivity $\left(\mathrm{mm} \mathrm{day}^{-1}\right), \gamma$ is the soil-dependent constant, $\theta$ is soil moisture $\left(\mathrm{m}^{3} \mathrm{~m}^{-3}\right)$, and $\theta_{\mathrm{o}}$ is saturated soil moisture $\left(\mathrm{m}^{3} \mathrm{~m}^{-3}\right)$.

Table 4 shows the values of the parameters of the equation (5) for the different soil depths.

\section{Soil water flux density}

To determine deep drainage or capillary rise (descending or ascending flow) at the lower limit of the soil volume $(Z=0.60 \mathrm{~m})$, the Darcy-Buckingham equation was used according to equation 6 :

$$
D / A=-K(\theta) \frac{\Delta \phi_{t}}{z} D / A=-K(\theta) \frac{\Delta \phi_{t}}{z}
$$


Where $\mathrm{D} / \mathrm{A}$ is the soil water flux density ( $\mathrm{mm}$ day $\left.^{-1}\right), K(\theta)$ is the unsaturated soil hydraulic conductivity $\left(\mathrm{mm}\right.$ day $\left.^{-1}\right), \Delta \varphi_{\mathrm{t}} / \mathrm{z}$ is the total potential gradient, $\Phi_{\mathrm{t}}$ is total soil water potential $(\mathrm{m})$, and $\mathrm{z}$ is the vertical position coordinate $(\mathrm{m})$.

The total potential at each depth was calculated by the equation (7):

$$
\phi_{t}=\phi_{m}+\phi_{g}
$$

Where $\phi_{g}$ is the gravitational potential (m).

The matric potential $\left(\phi_{\mathrm{m}}\right)$, in $\mathrm{m}$ of water, was calculated according to the equation (8):

$$
-\phi_{m}=R t \times 0,1-(h t+h c)
$$

Where Rt is the tensiometer reading $(\mathrm{kPa}), \mathrm{Ht}$ is the height of the tensiometric tube above the soil (m), and hc is the installation depth of the tensiometer $(\mathrm{m})$.

\section{solution}

Movement of nitrate and potassium in the soil

In the plant rows of each plot, porous cup extractors were installed near the tensiometers at the depths 0.40 and $0.60 \mathrm{~m}$. The soil solution was removed by vacuum $(-80$ $\mathrm{kPa}$ ) using a hand pump one day after each fertigation event until the end of crop growing seasons. The samples were composed by treatment and by depth. The analyses of nitrate concentration in the soil solution were performed using a specific Horiba ${ }^{\circledR}$ cardiometer, while potassium analyses were performed using flame photometry. Assuming the movement only by mass flow, the flux density of each nutrient at a given depth was determined by the product between water flux density and nutrient concentration at a given time interval, equation 9:

$$
q N U T=q H_{2} O x c N U T
$$

Where $q N U T$ is the nutrient flux density $\left(\mathrm{kg} \mathrm{ha}^{-1}\right.$ day $\left.^{-1}\right), \mathrm{qH}_{2} \mathrm{O}$ is the soil water flux density $\left(\mathrm{m}^{3} \mathrm{~m}^{-2}\right.$ day $\left.^{-1}\right)$, and $c N U T$ is the mean nutrient concentration in the soil solution $\left(\mathrm{kg} \mathrm{L}^{-1}\right)$ per treatment, all at the depth $\mathrm{z}(\mathrm{m})$.

Soil water flux density was estimated by the equation 10:

$$
q \mathrm{H}_{2} \mathrm{O}=K(\theta) \times \operatorname{grad}(H)
$$

Where $K(\phi)$ is the unsaturated soil hydraulic conductivity $\left(\mathrm{m}^{3} \cdot \mathrm{m}^{2} \cdot\right.$ day $\left.^{-1}\right)$, and $\operatorname{grad}(H)$ is the hydraulic gradient of soil water.

The results were submitted to analysis of variance and then regression analysis at a $5 \%$ probability $(\mathrm{p}<0.05)$.

\section{Results and discussion}

\section{Soil moisture}

Due to the daily frequency of drip irrigation, the values of soil moisture $(\theta)$ in all grapevine growing seasons studied (Figure 1) were close to field capacity moisture. The $0.20 \mathrm{~m}$ depth presented values of $\theta$ with small variations for all growing seasons. The mean values were $0.16 \mathrm{~m}^{3} \mathrm{~m}^{-3}, 0.17 \mathrm{~m}^{3} \mathrm{~m}^{-3}$ and $0.17 \mathrm{~m}^{3} \mathrm{~m}^{-3}$ for the first, second and third growing seasons (Figure 1A, $1 \mathrm{~B}$ and $1 \mathrm{C}$, respectively). At $0.4 \mathrm{~m}$ and $0.60 \mathrm{~m}$ depths, the values of $\theta$ were similar in all the growing seasons studied, showing increases in moisture values in measurements performed a few hours after irrigation, as can be observed in the first 30 days after pruning (dap) of the third grapevine growing season.

According to Castellanos et al. (2013), the application of water may directly influence fertilizer losses since the excess of irrigation water depths causes leaching, while an efficient use of water, related to a correct irrigation management, reduces the risks of contamination of rivers and water sources by fertilizers. In this aspect, the drip irrigation system becomes a good option since its application efficiency is high, concentrating the application of nutrients in the crop root system (BARAKAT et al., 2016).

\section{Water balance}

For water balance during the first growing season (Table 5), rainfall $(\mathrm{Rn})$ results were only $13.0 \mathrm{~mm}$, with a maximum $\mathrm{Rn}$ of $5.5 \mathrm{~mm}$ on the $28^{\text {th }}$ dap. Thus, irrigation was responsible for making available all the water consumed by the plants during this season by applying a total irrigation (I) of $600.7 \mathrm{~mm}$. During the second season, the total value of Rn was $99.2 \mathrm{~mm}$. At 61 dap, there was a $35.5 \mathrm{~mm}$ rainfall, raising soil water storage $(\Delta \mathrm{h})$ to field capacity (SWC) up to $0.60 \mathrm{~m}$ depth in the period between 14 and 88 dap. Due to the high rainfall in this period, there was a reduction in the total I, and 431.3 $\mathrm{mm}$ season $^{-1}$ were applied.

During the third growing season, the total Rn value was $71.6 \mathrm{~mm}$ and $64.4 \mathrm{~mm}$ occurred at 103 dap, which caused the irrigation interruption until the harvesting day. The total I during this season was $644 \mathrm{~mm}$, which was higher than the previous two seasons. The proper water management in grapevines is of great importance for a better quality of grapes. According to Bassoi et al. (2015) grape quality is influenced directly by water management, such as volume of must and concentration of tartaric acid. However, number and weight of bunches per plant did not change. Therefore, a correct quantification of irrigation management, in addition to avoiding the leaching of fertilizers, may result in significant results in the grape yield due to an efficient water use. 


\section{Movement of nitrate}

During the first grapevine season, at $0.4 \mathrm{~m}$ depth (Figure 2A), a maximum movement was $13 \mathrm{~kg} \mathrm{NO}_{3}^{-} \mathrm{ha}^{-1}$. At $0.6 \mathrm{~m}$ depth (Figure 2B), the movement was higher $\left(62.2 \mathrm{~kg} \mathrm{NO}_{3}^{-} \mathrm{ha}^{-1}\right)$ in relation to application of $120 \mathrm{~kg}$ $\mathrm{N} \mathrm{ha}{ }^{-1}$. These results are similar to those presented by Lorensini et al. (2012) in a vineyard in Southern Brazil, in which the highest concentration of mineral nitrogen in the leached solution at $0.20 \mathrm{~m}$ depth were found when higher dose (120 kg N ha-1 year-1) of mineral fertilizer (urea) was applied in a Sandy Typic Hapludalf soil (clay content of $70 \mathrm{~g} \mathrm{~kg}^{-1}$ in $0.20 \mathrm{~m}$ layer).

During the second grapevine season, there was an increase in the movement of $\mathrm{NO}_{3}{ }^{-}$at $0.4 \mathrm{~m}$ depth (Figure $2 \mathrm{C})$ possibly due to an acceleration of the nitrification process caused by several factors such as availability of soil water (BARAKAT et al., 2016), chemical conditions related to $\mathrm{pH}$ (HAN et al., 2015) and even soil physical conditions such as texture ( $74 \%$ of sand). However, such losses may not influence crop production since, according to the literature (ROCHA et al., 2015; ARROBAS et al., 2014), the application of high doses of $\mathrm{N}$ (above $80 \mathrm{~kg} \mathrm{~N}$ $\mathrm{ha}^{-1}$ ) to the soil did not increase plant yield. Compared to the previous season, the movement of $\mathrm{NO}_{3}{ }^{-}$at $0.6 \mathrm{~m}$ depth (Figure 2D) was lower, presenting maximum values of $48.6 \mathrm{~kg} \mathrm{NO}_{3}^{-} \mathrm{ha}^{-1}$. During the third grapevine season, there was a high movement of $\mathrm{NO}_{3}^{-}$at both studied depths. At the end of the fertigation period, the $0.4 \mathrm{~m}$ depth (Figure $2 \mathrm{E})$ showed a minimum movement of $14 \mathrm{~kg} \mathrm{NO}_{3}{ }^{-} \mathrm{ha}^{-1}(15$ $\left.\mathrm{kg} \mathrm{Nha}{ }^{-1}\right)$ and a maximum movement of $61 \mathrm{~kg} \mathrm{NO}_{3}^{-} \mathrm{ha}^{-1}$ $\left(120 \mathrm{~kg} \mathrm{~N} \mathrm{ha}^{-1}\right)$, whereas at $0.6 \mathrm{~m}^{\text {depth }}$ (Figure 2F) there was a high movement of $\mathrm{NO}_{3}^{-}$at deeper layers, with a value above $50 \mathrm{~kg} \mathrm{NO}_{3}^{-}$ha $^{-1}$ for the highest dose of $\mathrm{N}$ applied.

In the analysis of variance for the movement of $\mathrm{NO}_{3}{ }^{-}$at 0.40 and $0.60 \mathrm{~m}$ soil depths, significant differences were observed for the factor $\mathrm{N}$ doses for all studied seasons, except for $0.60 \mathrm{~m}$ (second season) and $0.40 \mathrm{~m}$ (third season) depths.

In the data regression analysis, the adjustment model adopted in the first growing season at $0.4 \mathrm{~m}$ depth was linear (Figure 3A) with a movement of $0.044 \mathrm{~kg} \mathrm{NO}_{3}$ $\mathrm{ha}^{-1}$ for each unit increase in the $\mathrm{N}$ dose applied to the soil. At $0.60 \mathrm{~m}$ depth (Figure 3B) the adjustment adopted was quadratic and presented a greater movement in the $\mathrm{N}$ dose of $120 \mathrm{~kg} \mathrm{~N}^{-1}{ }^{-1}$ with values of $\mathrm{NO}_{3}^{-}$estimated in 115,40 $\mathrm{kg} \mathrm{NO}_{3}{ }^{-} \mathrm{ha}^{-1}$. During the second growing season, there was an increase of $0.099 \mathrm{~kg} \mathrm{NO}_{3}^{-} \mathrm{ha}^{-1}$ at $0.40 \mathrm{~m}$ depth (Figure $3 \mathrm{C})$ for each unit increase in the $\mathrm{N}$ dose applied.

There was a considerable increase in the $\mathrm{NO}_{3}{ }^{-}$ movement during the first and second grapevine growing seasons. Soil texture ( $74 \%$ sand) and low soil CEC (6.3 $\mathrm{cmol}_{c} \mathrm{dm}^{-3}$ ) may have had a significant influence on the $\mathrm{NO}_{3}{ }^{-}$movement due to low ion adsorption by soil matrix and despite the high efficiency of the drip irrigation system for fertilizer application (BORSSOI et al., 2012). There was a high movement as the $\mathrm{N}$ doses applied by fertigation increased, as occurred during the third growing season at $0.60 \mathrm{~m}$ depth (Figure 3D), in which there was a $\mathrm{NO}_{3}$ movement of $0.155 \mathrm{~kg} \mathrm{NO}_{3}^{-} \mathrm{ha}^{-1}$ for each increase unit in $\mathrm{N}$ dose applied to the soil by fertigation.

Min et al.(2016) and Silva et al. (2016) have demonstrated that high rate of water infiltration in sandy soil can contribute to $\mathrm{N}$ movement to deep layers affecting $\mathrm{NO}_{3}{ }^{-}$availability in the root zone to the plants. The leaching of $\mathrm{NO}_{3}^{-}$to water table is maximized by sandy texture, low organic matter, high permeability, low water holding capacity and high water application (GHIBERTO et al., 2015).

\section{Movement of potassium}

Although the $\mathrm{K}^{+}$mobility in the soil is low and occurs mainly by diffusion (SILVA et al., 2016; SILVA et al., 2014) there were high movements of this ion at 0.4 $\mathrm{m}$ and $0.6 \mathrm{~m}$ depths in relation to increases in $\mathrm{K}_{2} \mathrm{O}$ doses applied by fertigation. During the first growing season we observed a movement of $9 \mathrm{~kg} \mathrm{~K}^{+} \mathrm{ha}^{-1}$ at $0.4 \mathrm{~m}$ depth (Figure 4A), and of $16 \mathrm{~kg} \mathrm{~K}^{+} \mathrm{ha}^{-1}$ at $0.60 \mathrm{~m}$ depth (Figure 4B) for $120 \mathrm{~kg} \mathrm{~K}_{2} \mathrm{O} \mathrm{ha}{ }^{-1}$ doses.

During the second season, there was an increase in the $\mathrm{K}^{+}$movement, with values of $20.9 \mathrm{~kg} \mathrm{~K}^{+} \mathrm{ha}^{-1}$ (Figure 4C) at $0.4 \mathrm{~m} \mathrm{depth}$, and $30.56 \mathrm{~kg} \mathrm{~K}^{+} \mathrm{ha}^{-1}$ at $0.6 \mathrm{~m}$ depth (Figure 4D) for the $120 \mathrm{~kg} \mathrm{~K}_{2} \mathrm{O} \mathrm{ha}^{-1}$ dose. Possibly, the high movement of $\mathrm{K}^{+}$can be attributed to the low CEC and the good soil drainage, since $\mathrm{K}$ is little adsorbed by the soil. During the third season, there was a decrease in movement in relation to previous seasons, with maximum values of $20.03 \mathrm{~kg} \mathrm{~K}^{+} \mathrm{ha}^{-1}$ at $0.4 \mathrm{~m}$ depth (Figure 4E), and $13.14 \mathrm{~kg} \mathrm{~K}^{+} \mathrm{ha}^{-1}$ at $0.6 \mathrm{~m}$ depth (Figure 4F) for the $120 \mathrm{~kg}$ $\mathrm{K}_{2} \mathrm{O}$ ha $^{-1}$ dose.

The analysis of variance (F test) for the movement of $\mathrm{K}^{+}$in the different grapevine growing seasons and soil depths showed significant differences for $0.40 \mathrm{~m}$ depth during the first and second seasons. There was the interaction among $\mathrm{N}$ and $\mathrm{K}_{2} \mathrm{O}$ doses during the first season and only among doses of $\mathrm{K}_{2} \mathrm{O}$ during the second season cycle at 1 and $5 \%$ probability, respectively.

For the first growing season, the response surface in the movement at $0.40 \mathrm{~m}$ depth (Figure 5A) indicates a progressive increase of $\mathrm{K}^{+}$in $0.0458 \mathrm{~kg} \mathrm{~K}^{+} \mathrm{ha}^{-1}$ for doses of $\mathrm{N}$ and $0.0205 \mathrm{~kg} \mathrm{~K}^{+} \mathrm{ha}^{-1}$ for doses of $\mathrm{K}_{2} \mathrm{O}$. The highest value $\left(8.46 \mathrm{~kg} \mathrm{~K}^{+} \mathrm{ha}^{-1}\right)$ was observed when doses of $120 \mathrm{~kg} \mathrm{ha}^{-1}$ of $\mathrm{N}$ and $\mathrm{K}_{2} \mathrm{O}$ were applied. If fertilizers containing these two ions are used together in fertigation, the interaction between them may occur (SILVA et al., 2016). During the second growing season, at $0.40 \mathrm{~m}$ depth (Figure 5B), there was a linear adjustment, with an increase of $0.049 \mathrm{~kg} \mathrm{~K}^{+} \mathrm{ha}^{-1}$ for the $\mathrm{K}^{+}$movement for each unit increase in $\mathrm{K}_{2} \mathrm{O}$ doses applied. Silva et al. (2014b) observed an increase in the $\mathrm{K}^{+}$concentration in the soil solution according to increase in $\mathrm{K}_{2} \mathrm{O}$ doses applied in an area close to this experiment. 
Table 1 - Physical attributes of an Argissolo Vermelho Amarelo Eutrófico plintossólico (experimental area).

\begin{tabular}{|c|c|c|c|c|c|c|c|}
\hline \multirow[b]{2}{*}{ Depth } & \multirow[b]{2}{*}{$\mathrm{Sd}$} & \multirow[b]{2}{*}{$\mathrm{Pd}$} & \multirow[b]{2}{*}{ ТP } & \multicolumn{3}{|c|}{ Particle size } & \multirow[b]{2}{*}{ Classification } \\
\hline & & & & Sand & Silt & Clay & \\
\hline M & $\mathrm{kg} \mathrm{cm}^{-3}$ & $\mathrm{~kg} \mathrm{~cm}^{-3}$ & $(\%)$ & \multicolumn{3}{|c|}{---------'g kg-1---------- } & \\
\hline $0-0.20$ & 1.23 & 2.54 & 51.41 & 764.3 & 171.18 & 64.50 & Sandy loam \\
\hline $0.20-0.40$ & 1.24 & 2.53 & 51.08 & 737.7 & 180.38 & 81.88 & Sandy loam \\
\hline $0.40-0.60$ & 1.30 & 2.55 & 49.13 & 721.4 & 139.61 & 139.00 & Sandy loam \\
\hline
\end{tabular}

Sd - soil density; Pd - particle density; TP - total porosity

Table 2 - Chemical attributes of an Argissolo Vermelho Amarelo Eutrófico plintossólico before the beginning of fertigation.

\begin{tabular}{|c|c|c|c|c|c|c|c|c|c|c|}
\hline \multirow{2}{*}{$\begin{array}{l}\text { Depth } \\
\text { (m) }\end{array}$} & \multirow{2}{*}{ 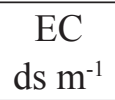 } & \multirow{2}{*}{$\begin{array}{l}\mathrm{pH} \\
\mathrm{H}_{2} \mathrm{O}\end{array}$} & \multirow{2}{*}{$\begin{array}{l}\mathrm{OM} \\
\mathrm{g} \mathrm{dm}^{-3}\end{array}$} & \multirow{2}{*}{\multicolumn{2}{|c|}{$---\mathrm{mg} \mathrm{kg}^{-1}----$}} & $\mathrm{P}$ & $\mathrm{K}$ & $\mathrm{K}$ & $\mathrm{Ca}$ & $\mathrm{Mg}$ \\
\hline & & & & & & \multicolumn{2}{|c|}{---mg dm ${ }^{-3}---$} & \multicolumn{3}{|c|}{----- $\mathrm{cmol}_{\mathrm{c}} \mathrm{dm}^{-3}$---- } \\
\hline $0-0.20$ & 0.7 & 7.5 & 20.8 & 4.28 & 4.86 & 156.9 & 351 & 0.9 & 3.5 & 1.3 \\
\hline $0.20-0.40$ & 0.5 & 7.2 & 15.2 & 3.50 & 4.67 & 123.9 & 234 & 0.6 & 3.1 & 1.1 \\
\hline $0.40-0.60$ & 0.32 & 6.81 & 8.92 & 3.11 & 4.08 & 93.79 & 156 & 0.4 & 2.8 & 1.1 \\
\hline \multirow{2}{*}{$\begin{array}{c}\text { Depth } \\
(\mathrm{m})\end{array}$} & $\mathrm{Na}$ & $\mathrm{H}+\mathrm{Al}$ & BS & CEC & $\mathrm{V}$ & & & $\mathrm{Fe}$ & $\mathrm{Mn}$ & $\mathrm{Zn}$ \\
\hline & \multicolumn{4}{|c|}{-------cmol $\mathrm{dm}^{-3}-------$} & $(\%)$ & \multicolumn{5}{|c|}{ 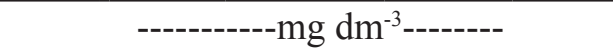 } \\
\hline $0-0.20$ & 0.1 & 1.1 & 5.8 & 7.0 & 83.3 & 1.75 & & & 61.6 & 21.5 \\
\hline $0.20-0.40$ & 0.1 & 1.3 & 4.9 & 6.2 & 78.8 & 2.49 & & & 46.4 & 19.8 \\
\hline $0.40-0.60$ & 0.08 & 1.4 & 4.4 & 5.8 & 75.7 & 4.71 & & & 26.9 & 12.2 \\
\hline
\end{tabular}

$\mathrm{CE}$ - electric conductivity of the saturation extract; $\mathrm{OM}$ - organic matter; $\mathrm{NO}_{3}{ }^{-}$- nitrate; $\mathrm{NH}_{4}^{+}$ammonium; $\mathrm{P}$ - phosphorus; $\mathrm{K}$ - potassium; Ca - calcium; $\mathrm{Mg}$ - magnesium; $\mathrm{Na}$ - sodium; $\mathrm{H}+\mathrm{Al}$ - potential acidity; $\mathrm{BS}$ - base sum; CEC - cation exchange capacity; V (\%) - base saturation; $\mathrm{Cu}$ - copper; $\mathrm{Fe}$ - iron: Mn-manganese; Zn-zinc.

Table 3 - Parameters of the van Genutchen equation describing water retention curves in the three soil layers of an Argissolo Vermelho-Amarelo Eutrófico plintossólico.

\begin{tabular}{cccccc}
\hline Depth $(\mathrm{m})$ & $\alpha$ & $\mathrm{m}$ & $\mathrm{n}$ & $\theta \mathrm{r}\left(\mathrm{m}^{3} \mathrm{~m}^{-3}\right)$ & $\theta \mathrm{s}\left(\mathrm{m}^{3} \mathrm{~m}^{-3}\right)$ \\
\hline $0-0.20$ & 1.338 & 0.182 & 3.123 & 0.086 & 0.393 \\
$0.20-0.40$ & 0.707 & 0.203 & 2.311 & 0.092 & 0.317 \\
$0.40-0.60$ & 1.217 & 0.170 & 3.809 & 0.117 & 0.489 \\
\hline
\end{tabular}

$\theta \mathrm{r}$ - residual moisture, $\theta \mathrm{s}$ - saturation moisture; $\alpha, \mathrm{m}, \mathrm{n}$ - empirical parameters of the equation

Table 4- Values of of saturated hydraulic conductivity $\left(\mathrm{K}_{\mathrm{o}}, \mathrm{m}^{2} \mathrm{~h}^{-1} \mathrm{KPa}^{-1}\right), \gamma$ and soil water saturation $\left(\theta_{\mathrm{o}}, \mathrm{m}^{3} \mathrm{~m}^{-3}\right)$ at 0.20, 0.40 and $0.60 \mathrm{~m}$ depths of an Argissolo Vermelho-Amarelo Eutrófico plintossólico.

\begin{tabular}{cccc}
\hline Depth $(\mathrm{m})$ & $\mathrm{K}_{\circ}$ & $\mathrm{r}$ & $\theta$ \\
\hline 0.20 & 1.200 & 16.839 & 0.395 \\
0.40 & 2.813 & 20.408 & 0.315 \\
0.60 & 1.906 & 19.155 & 0.324 \\
\hline
\end{tabular}



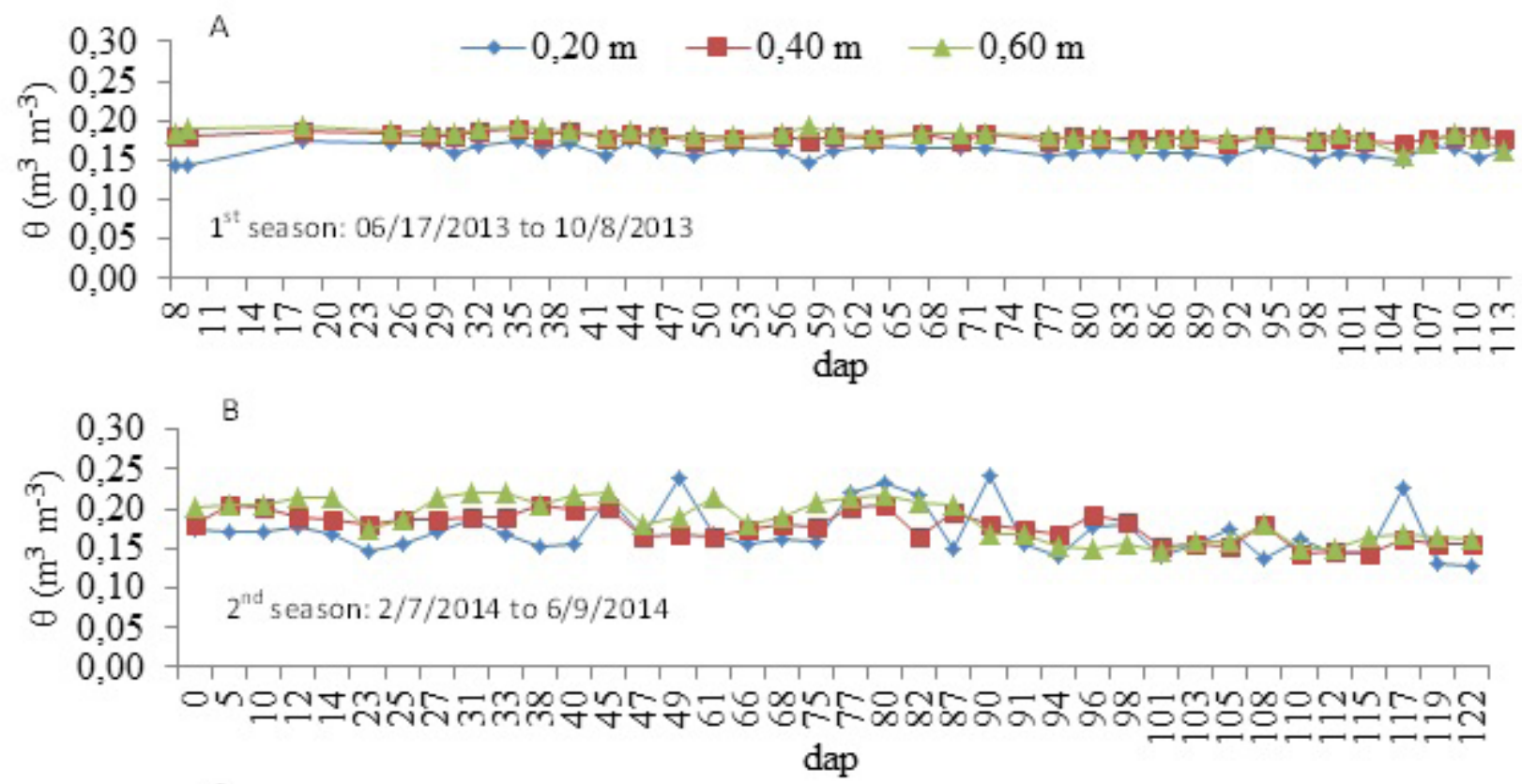

C

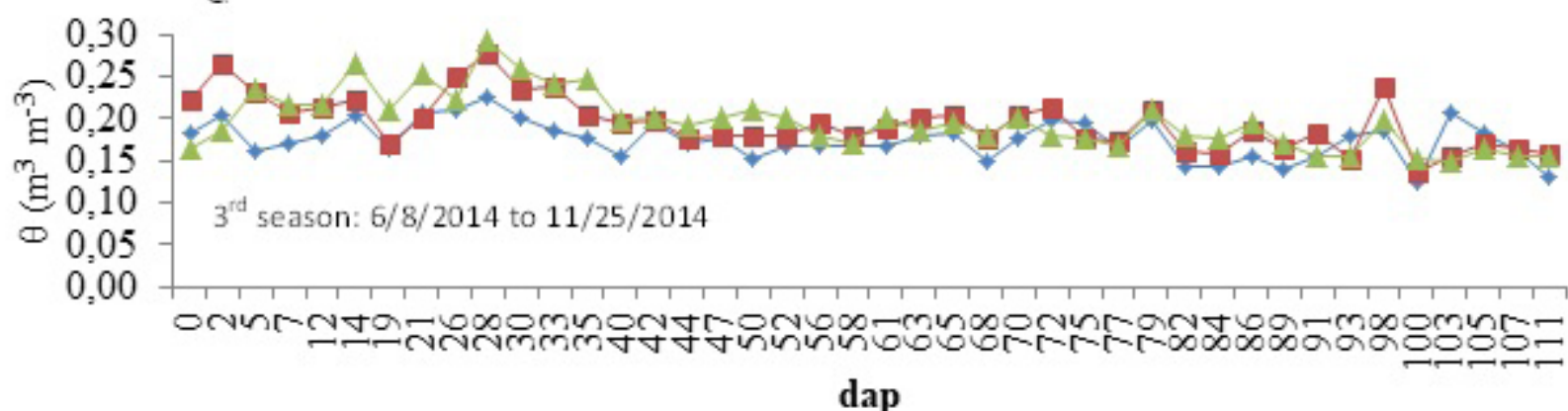

Figure 1 - Soil water content during the first (A), second (B) and third (C) growing seasons of grapevine cv. Syrah/ Paulsen 1103 in Petrolina, PE, according to days after pruning (dap). 
Table 5 - Variation in soil water storage $(\Delta \mathrm{h})$, irrigation $(\mathrm{I})$, rainfall $(\mathrm{Rn})$, deep drainage / capillary rise (D/A) and crop evapotranspiration (ETc) in three growing seasons of grapevine cv. Syrah/Paulsen 1103.

\begin{tabular}{|c|c|c|c|c|c|c|}
\hline \multirow{3}{*}{ Period (dap) } & \multirow{3}{*}{$\mathrm{PF}$} & $\Delta \mathrm{h}$ & $\mathrm{I}$ & $\mathrm{Rn}$ & $\mathrm{D} / \mathrm{A}$ & ETc \\
\hline & & \multicolumn{5}{|c|}{ 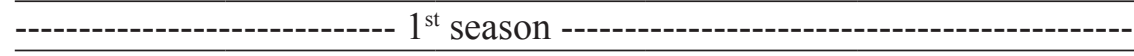 } \\
\hline & & \multicolumn{5}{|c|}{ (----------- mm ----------- } \\
\hline $8-28$ & $\mathrm{UL}-\mathrm{SF}$ & -5.41 & 133.02 & 7.50 & -7.32 & 122.41 \\
\hline $30-39$ & FL & 3.23 & 65.72 & 3.60 & -12.48 & 59.15 \\
\hline $42-52$ & PS & 11.30 & 66.75 & 1.90 & -13.40 & 59.91 \\
\hline $56-67$ & PS-BC & -7.42 & 92.73 & 0.00 & -8.04 & 83.46 \\
\hline $70-81$ & CB-VE & 5.13 & 85.89 & 0.00 & -12.39 & 77.30 \\
\hline $84-94$ & VE & -0.98 & 71.15 & 0.00 & -11.85 & 64.04 \\
\hline $98-105$ & $\mathrm{R}$ & 10.03 & 49.73 & 0.00 & -11.38 & 44.76 \\
\hline $107-113$ & $\mathrm{R}$ & 6.65 & 35.73 & 0.00 & -16.19 & 32.15 \\
\hline \multirow[t]{2}{*}{ Total } & & 22.53 & 600.72 & 13.00 & -93.05 & 543.18 \\
\hline & \multicolumn{6}{|c|}{------------------------------- 2nd season --------------------------- } \\
\hline $5-14$ & UL & 0.00 & 51.70 & 29.70 & -6.05 & 72.47 \\
\hline $23-33$ & $\mathrm{SF}-\mathrm{FL}$ & 4.91 & 99.74 & 2.60 & -3.82 & 99.57 \\
\hline $38-49$ & PS & 0.38 & 98.51 & 0.00 & -9.85 & 88.66 \\
\hline $61-77$ & $\mathrm{CB}$ & 0.48 & 69.16 & 45.70 & -5.96 & 107.00 \\
\hline $80-91$ & VE & -6.2 & 36.23 & 18.00 & -20.74 & 39.31 \\
\hline $94-103$ & VE & 21.03 & 26.90 & 0.00 & -13.80 & 24.21 \\
\hline $105-112$ & $\mathrm{R}$ & 12.03 & 21.48 & 3.20 & -9.15 & 19.75 \\
\hline $115-122$ & $\mathrm{R}$ & 32.06 & 27.59 & 0.00 & -12.92 & 24.83 \\
\hline \multirow[t]{2}{*}{ Total } & & 64.69 & 431.31 & 99.20 & -82.29 & 475.80 \\
\hline & \multicolumn{6}{|c|}{-------------------------------- 3 ${ }^{\text {rd }}$ season ----------------------------- } \\
\hline $2-12$ & $\mathrm{UF}-\mathrm{SF}$ & 6.3 & 47.5 & 3.9 & -9.9 & 42.6 \\
\hline $14-28$ & $\mathrm{SF}-\mathrm{FL}$ & 12.9 & 123.2 & 0.0 & -12.6 & 110.9 \\
\hline $30-42$ & $\mathrm{FL}-\mathrm{PS}$ & 0.1 & 117.0 & 0.0 & -7.2 & 105.3 \\
\hline $44-56$ & PS & 4.7 & 99.5 & 0.0 & -10.3 & 89.6 \\
\hline $58-68$ & VE & 7.0 & 69.6 & 0.3 & -10.6 & 62.7 \\
\hline $70-79$ & VE & -3.8 & 74.1 & 0.0 & -18.4 & 66.6 \\
\hline $82-89$ & $\mathrm{R}$ & 0.3 & 67.3 & 0.0 & -5.3 & 60.6 \\
\hline $91-100$ & $\mathrm{R}$ & 14.3 & 43.2 & 1.1 & -16.3 & 38.9 \\
\hline $103-111$ & $\mathrm{R}$ & 0.0 & 3.1 & 66.3 & -23.9 & 2.8 \\
\hline Total & & 41.8 & 644.5 & 71.6 & -114.5 & 580.0 \\
\hline
\end{tabular}

dap - days after pruning, PP - phenological phase, UL - unfolded leaf SF - separate flowers, FL - flowering, PS - pea size berries, CB - closure bunch, VE veraison and $\mathrm{R}$ - ripening 

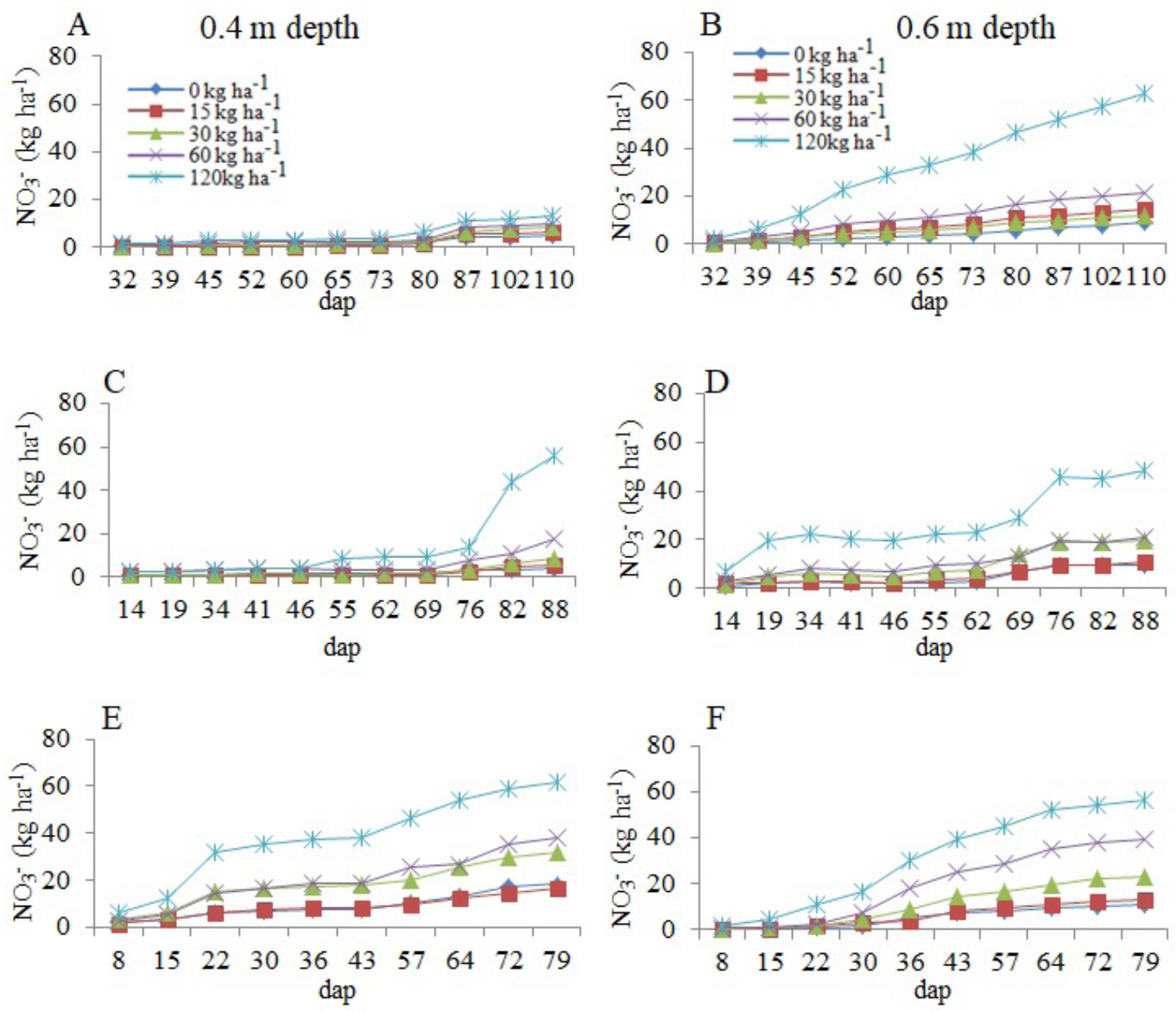

Figure 2 - Accumulated movement of nitrate in the soil during fertigation events according to days after pruning (dap) at the $0.40 \mathrm{~m}(\mathrm{~A})$ and $0.60 \mathrm{~m}(\mathrm{~B})$ depths - first growing season, $0.40 \mathrm{~m}(\mathrm{C})$ and $0.60 \mathrm{~m}(\mathrm{D})$ - second growing season, and $0.40 \mathrm{~m}(\mathrm{E})$ and $0.60 \mathrm{~m}(\mathrm{~F})$ - third growing season of grapevine cv. Syrah/Paulsen 1103. 

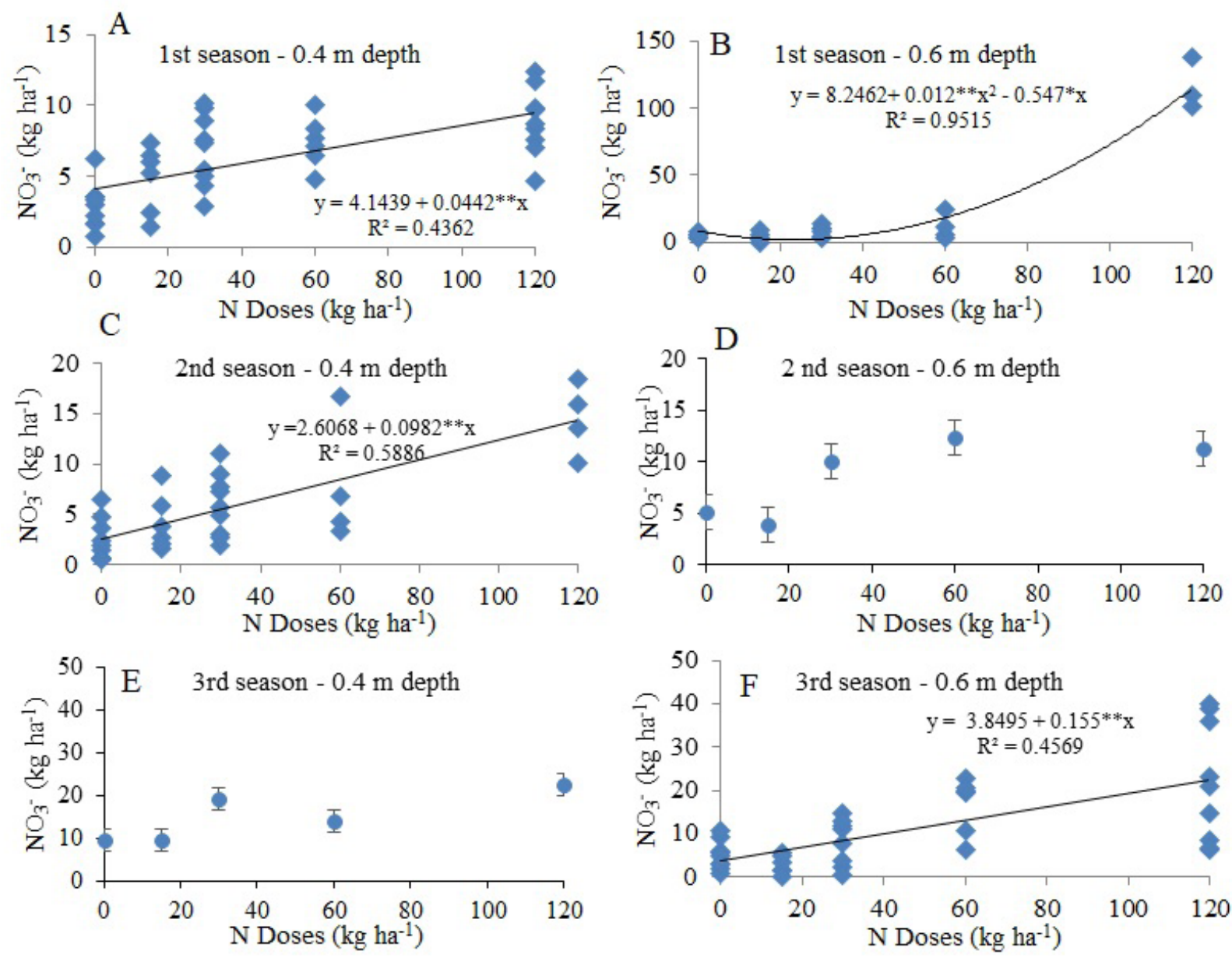

Figure 3 - Regression analysis for the movement of nitrate at $0.4 \mathrm{~m}(\mathrm{~A}, \mathrm{C}$ and $\mathrm{E})$ and $0.6 \mathrm{~m}$ soil depths (B, D and F) in three growing seasons of grapevine cv. Syrah/Paulsen $1103 .{ }^{*}$ and $* *$ : significant at $1 \%$ and $5 \%$, respectively, by T test; 
A
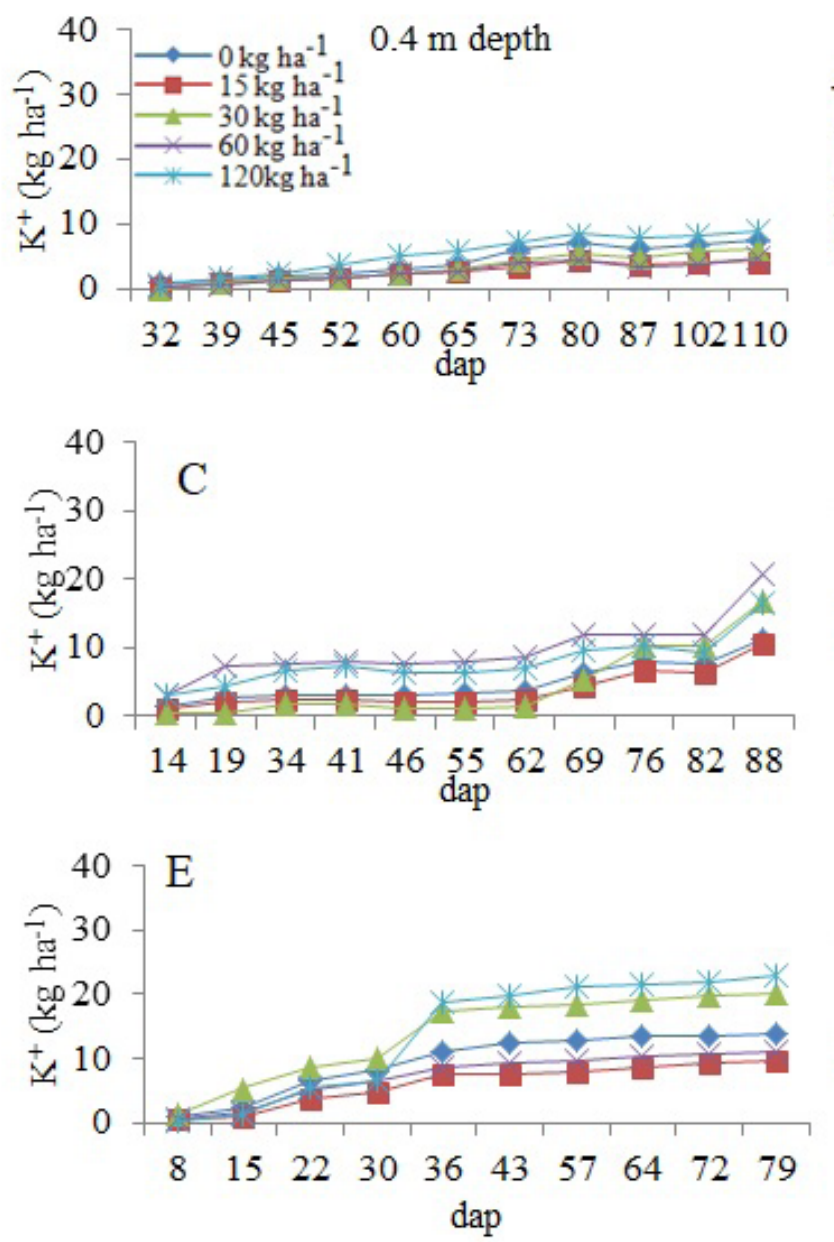

B
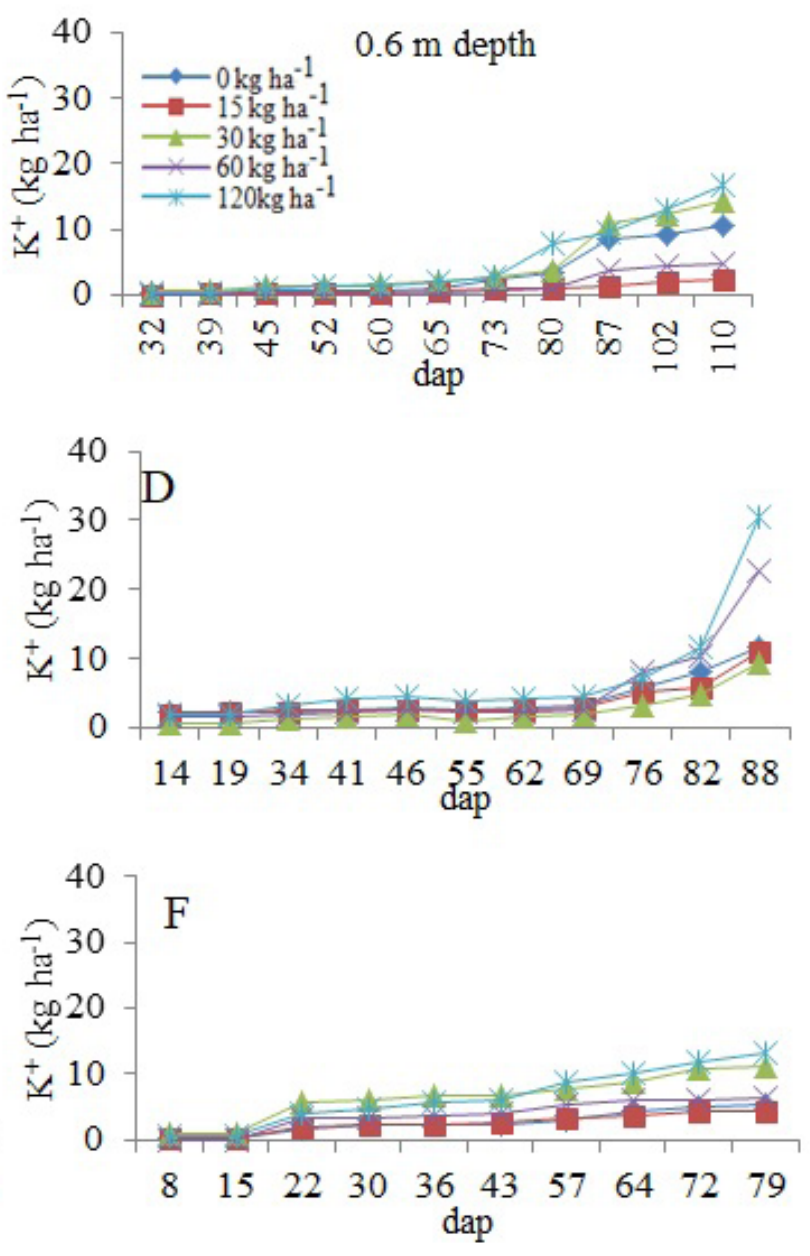

Figure 4 - Accumulated movement of potassium in the soil during fertigation events according to days after pruning (dap) at $0.40 \mathrm{~m}(\mathrm{~A})$ and $0.60 \mathrm{~m}(\mathrm{~B})$ depths - first growing season, $0.40 \mathrm{~m}(\mathrm{C})$ and $0.60 \mathrm{~m}$ (D) depths - second growing season, and $0.40 \mathrm{~m}$ (E) and $0.60 \mathrm{~m}$ (F) depths - third growing season of grapevine cv. Syrah/Paulsen 1103, in Petrolina. 

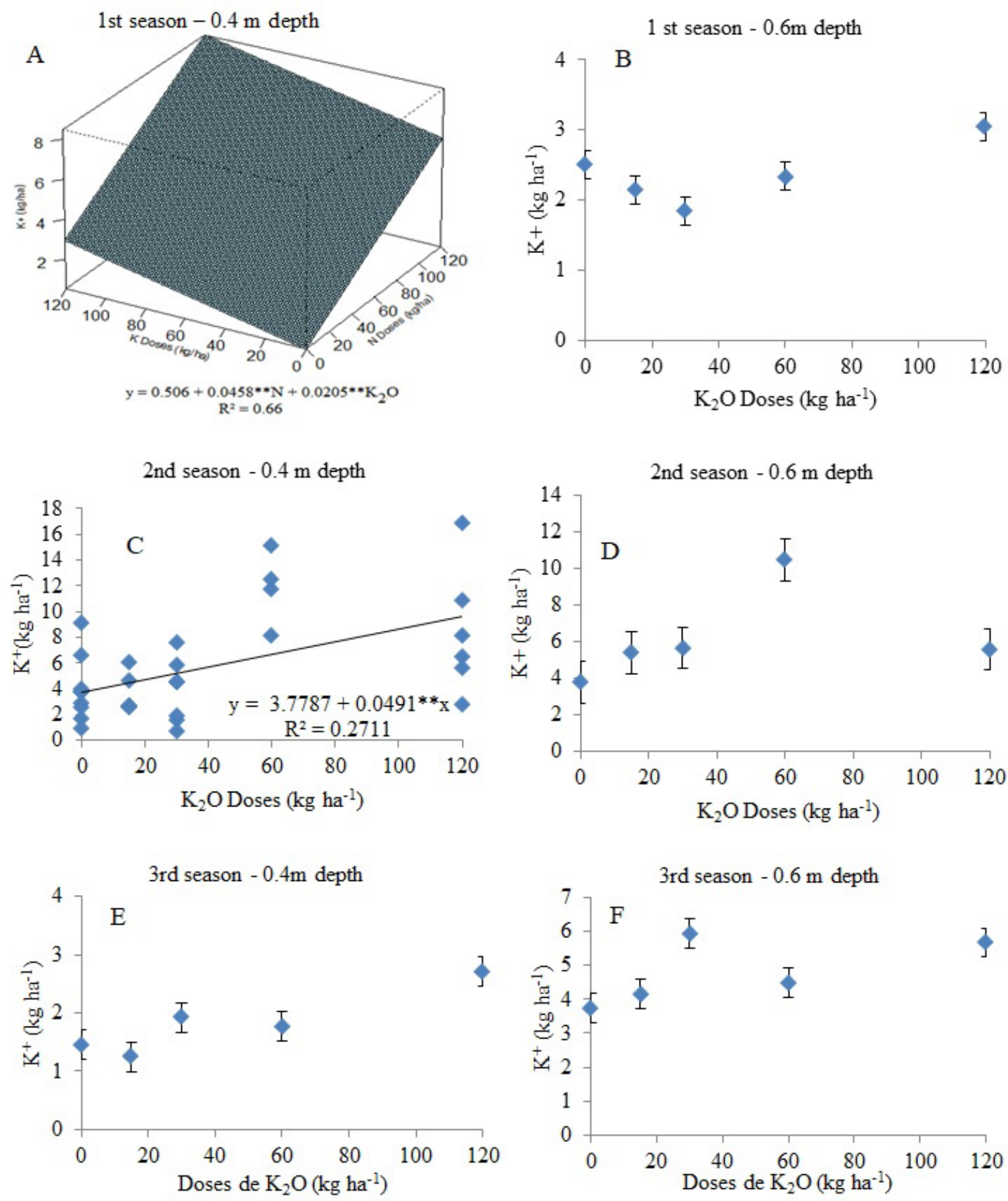

Figure 5 - Regression analysis for the soil movement of potassium at $0.4 \mathrm{~m}(\mathrm{~A})$ and $0.6 \mathrm{~m}(\mathrm{~B})$ depth in the first growing season, $0.4 \mathrm{~m}(\mathrm{C})$ and $0.6 \mathrm{~m}(\mathrm{D})$ in second growing seasons and $0.4(\mathrm{E}) \mathrm{m}$ and $0.6 \mathrm{~m}(\mathrm{~F})$ in third growing season of grapevine cv. Syrah/Paulsen $1103 . *$ and $* *$ : significant at $1 \%$ and $5 \%$ respectively, by $\mathrm{T}$ test. 


\section{Conclusions}

The increase in doses of $\mathrm{N}$ and $\mathrm{K}_{2} \mathrm{O}$ applied through drip fertigation during three grapevine growing seasons enhanced the movement of $\mathrm{NO}_{3}{ }^{-}$and $\mathrm{K}^{+}$in a sandy soil of Brazilian semiarid. Despite the efficiency of drip fertigation, a greater split of fertilizer application is recommended to minimize downward movement of nutrients in the soil.

\section{References}

ALBUQUERQUE, A.H.P.VIANNA, T.V.A.; MARINHO, A.B.; SOUSA, G.G.; AZEVEDO, B.M. Irrigação e fertirrigação potássica na cultura da videira em condições semiáridas. Pesquisa Agropecuária Tropical, Goiânia, v.43, n.3, p.315-321, 2013. Disponível em: $\leq \mathrm{http}: / / \mathrm{www}$. scielo.br/pdf/pat/v43n3/a09.pdf?origin=publication detail $>$ Acesso em: 17 oct. 2016.

ALVES, W.B.; ROLIM, G.S.; APARECIDO, L.E.O. Reference evapotranpiration forecasting by artificial neural networks. Engenharia Agrícola, Jaboticabal, v.37, n.6, p.1116-1125, 2017. Disponível em: $\leq$ http://doi. org/10.1590/1809-4430-Eng.Agric.v37n6p1125/2017>. Acesso em: 11 mar. 2018.

ANDRADE, E.M.; AQUINO, D.N.; LUNA, N.R.S.; LOPES, F.B.; CRISÓSTOMO, L.A. Dinâmica do nível freático e da salinização das águas subterrâneas em áreas irrigadas. Revista Ceres, Viçosa, MG, v.63, n.5, p.621630, 2016. Disponível em: $<$ http://doi.org/10.1590/0034737X201663050005> Acesso em: 11 mar. 2018.

ARROBAS, M. FERREIRA, I.Q.; FREITAS, S.; VERDIAL, J.; RODRIGUES, M.A. Guidelines for fertilizer use in vineyards based on nutrient content of grapevine parts. Scientia Horticulturae, Amsterdam, v.122, n.1, p.191-198, 2014.

ASSIS, P.C.R.; STONE, L.F.; MEDEIROS, J.C.; MADARI, B.E.; OLIVEIRA, J.M.; WRUCK, F.J. Atributos físicos do solo em sistema de integração lavourapecuária-floresta. Revista Brasileira de Engenharia Agrícola e Ambiental, Campina Grande, v.19, n.4, p.309316, 2015. Disponível em: $\leq$ http://doi.org/10.1590/18071929/agriambi.v.19n4p309-316>. Acesso em: 11 mar. 2018.
BADR, M.A.; ABOU-HUSSEIN, S.D.; EL-TOHAMY, W.A. Tomato yield, nitrogen uptake and water use efficiency as affected by planting geometry and level of nitrogen in an arid region. Agricultural Water Management, Amsterdam, v. 169, n. 1, p. 90-97, 2016. Disponível em: $\leq \mathrm{https}: / /$ doi.org/10.1016/j. agwat.2016.02.012>. Acesso em:January, 21, 2017.

BARAKAT, M.; CHEVIRON, B.; ANGULOJARAMILLO, R. Influence of the irrigation technique and strategies on the nitrogen cycle and budget: A review. Agricultural Water Management, Amsterdam, v.178, n.1, p.225-238, 2016. Disponível em: $<$ https://doi. org/10.1016/j.agwat.2016.09.027>. Acesso em: 22 jan. 2017.

BASSOI, L.H.; DANTAS, B. F.; LIMA FILHO, J. M. P.; LIMA, M.A.C.; LEÃO, P.C.S.; SILVA, D.J.; MAIA, J.L.T.; SOUZA, C.R.; SILVA, J.A.M.; RAMOS, M.M. Preliminary results of a long-term experiment about RDI and PRD irrigation strategies in winegrapes in São Francisco Valley, Brazil. Acta Horticulturae, Leuven, v.754, n.1, p.275-282, 2007.

BASSOI, L.H.CORREIA, J.S.; SANTOS, A.R.L.; SILVA, J.A.; COSTA, B.R.S. Deficit irrigation in grapevine Cv. Syrah during two growing seasons in the brazilian Semiarid. Engenharia Agrícola, Jaboticabal, v.35, n.3, p.430-441, 2015. Disponível em: $\leq \mathrm{http}: / /$ dx.doi.org/10.1590/18094430-Eng.Agric.v35n3p430-441/2015>. Acesso em: 11 sep. 2016.

BORSSOI, A.L.; VILLAS BOAS, M.A.; REISDÖRFER, M.; HERNÁNDEZ, R.H.; FOLLADOR, F.A.C. Water application uniformity and fertigation in a dripping irrigation set. Engenharia Agrícola, Jaboticabal, v.32, n.4, p.718-726. 2012. Disponível em: $<$ http://dx.doi. org/10.1590/S0100-69162012000400011>. Acesso em: 05 jun. 2016.

BORTOLOTTO, R.P.; BRUNO, I.P.; DOURADONETO, D.; TIMM, L.C.; SILVA, A.N.; REICHARDT, K. Nitrate leaching through climatologic water balance in a fertigated coffee plantation. Revista Ceres, Viçosa, MG, v.60, n.6, p.785-792, 2013. Disponível em: $\leq$ http://dx.doi. org/10.1590/S0034-737X2013000600006>. Acesso em: 11 nov. 2016

CASTELLANOS, M.T.; TARQUIS, A.M.; RIBAS, F.; CABELlO, M.J.; ARCE, A.; CARTAGENA, M.C. Nitrogen fertigation: An integrated agronomic and environmental study. Agricultural Water Management, Amsterdam, v.120, n.1, p.46-55, 2013. Disponível em: $\leq$ https://doi.org/10.1016/j.agwat.2012.06.016>. Acesso em: 21 jun. 2016. 
CONCEIÇÃO, B.S.; LIMA, L.A.; SANT'ANA, J.A.V.; SILVA, E.L.; ANDRADE, R.R. Difusividade e condutividade hidráulica não saturada de substrates. Revista Brasileira de Engenharia Agrícola e Ambiental, Campina Grande, v.18, n.6, p.607-614, 2014. Disponível em: $\leq$ http://doi.org/10.1590/S141543662014000600007>. Acesso em: 11 mar. 2018.

DONAGEMA, G.K.CAMPOS, D.V.B.de; CALDERANO, S.B.; TEIXEIRA, W.G.; VIANA, J.H.M. (Org.). Manual de métodos de análise de solos. 2.ed. rev. Rio de Janeiro: Embrapa Solos, 2011. 230p. (Documentos, 132).

DOURADO NETO, D.; NIELSEN, D.R.; HOPMANS, J.W.; REICHARDT, K.; BACHI, O.O.S. Software to model soil water retention curves (SWRC, version 3.00). Scientia Agricola, Piracicaba, v.57, n.1, p.191-192, 2000.

GHIBERTO, P. J.; LIBARDI, P. L.; TRIVELIN, P. C. O. Nutrient leaching in a Ultisoil cultivated with sugarcane. Agricultural Water Management, Amsterdam, v. 148, p.141-149, 2015. Disponível em: $\leq$ http://doi. org/10.1016/j.agwat.2014.09.027>. Acesso em: $18 \mathrm{mar}$. 2018.

HAN, J.; SHI, J., ZENG, L., XU, J., WU, L. Effects of nitrogen fertilization on the acidity and salinity of greenhouse soils. Environmental Science Pollution Research, Berlin, v. 22, n. 4, p. 2976-2986, 2015.

LITTEL, R.C.; MOTT, G.O. Computer assisted design and analysis of response surface experiments in agronomy. Soil and Crop Society of Florida Proceedings, Gainesville, v.34, n.1, p.94-97, 1975.

LORENSINI, F.; CERETTA, C. A.; GIROTTO, E.; CERINI, J. B.; LOURENZI, C. R.; CONTI, L.; TRINDADE, M. M.; MELO, G. W.; BRUNETTO, G. Lixiviação e volatilização de nitrogênio em um Argissolo cultivado com videira submetida à adubação nitrogenada. Ciência Rural, Santa Maria, v.42, n.7, p.1173-1179, 2012. Disponível em: $<$ http://dx.doi.org/10.1590/S010384782012005000038>. Acesso em: 10 jun. 2016.

MENDES, W.C.; ALVES JUNIOR, J.; CUNHA, P.C.R.; SILVA, A.R.; EVANGELISTA, A.W.P.; CASAROLI, D. Lixiviação de nitrato em função de lâminas de irrigação em solos argiloso e arenoso. Irriga, Botucatu, n.1, p.4756, 2015. Volume especial. Disponível em: $\leq$ http://dx.doi. org/10.15809/irriga.2015v1n2p47>. Acesso em: 19 sept. 2016.
MIN, W.; GUO, H.; ZHOU, G.; ZHANG, W.; MA, L.; YE, J.; HOU, Z.; WU, L. Soil salinity, leaching, and cotton growth as affected by saline water drip irrigation and $\mathrm{N}$ fertigation. Acta Agriculturae Scandinava, Section B - Soil \& Plant Science, v. 66, n.6, p.489-501, 2016. Disponível em: $\leq \mathrm{http} / /$ dx.doi.org/10.1080/09064710.20 16.1181199>. Acesso em: 10 mar. 2018.

QUAGGIO, J.A.; SOUZA, T.R.; ZAMBROSI, F.C.B.; BOARETTO, R.M.; MATTOS JUNIOR, D. Nitrogenfertilizer forms affect the nitrogen-use efficiency in fertigated citrus groves. Journal Plant Nutrition and Soil Science, Berlin, v.1, p.1-8, 2014. Disponível em: $<$ ttp:// onlinelibrary.wiley.com/doi/10.1002/jpln.201300315/ abstract>. Acesso em: 19 sep. 2016.

ROCHA, M.G.; BASSOI, L.H.; SILVA, D.J. Atributos do solo, produção da videira 'Syrah' irrigada e composição do mosto em função da adubação orgânica e nitrogenada. Revista Brasileira de Fruticultura, Jaboticabal, v.37, n.1, p.198-207, 2015. Disponível em: $\leq$ http://dx.doi. org/10.1590/0100-2945-412/13>. Acesso em: 14 sept. 2016.

SANTOS, H.G.; JACOMINE, P.K.T.; ANJOS, L.H.C.; OLIVEIRA, V.A.; LUMBRERAS, J.F.; COELHO, M.R.; ALMEIDA, J.A.de; CUNHA, T.J.F.; OLIVEIRA, J.B. de. Sistema brasileiro de classificação de solos. 3.ed. rev. e ampl. Brasília, DF: Embrapa, 2013. 353p.

SHARMA, R.; BHARDWAJ, S.; CHOUDHARY, M. Fertigation on fruits crops: a review. Annals of Biology, Cambridge, v.30, n.1, p.48-53, 2014.

SILVA, A.O.; SILVA, D.J.; BASSOI, L.H. Nitrate and potassium concentration in fertigated soil cultivated with wine vines. Ciência e Agrotecnologia, Lavras, v.40, n.3, p.305-316, 2016. Disponível em: $<$ http://dx.doi. org/10.1590/1413-70542016403042215>. Acesso em: 10 mar. 2018.

SOIL SURVEY STAFF. Keys to soil taxonomy. $25^{\text {th }}$ ed. Washington: United States Department of Agriculture, Natural Resources Conservation Service, 2014.360p.

SILVA, D. J.; SILVA, A. O.; BASSOI, L. H.; SILVA, B. R. S.; TEIXEIRA, R. P.; SOUZA, D. R. M. Adubação orgânica e fertirrigação potássica em videira 'Syrah' no Semiárido. Irriga, Botucatu, n.1, p.168-178, 2014. Volume especial. Disponível em: $\leq$ http://dx.doi.org/10.15809/ irriga.2014v1n1p168>. Acesso em: 22 aug. 2016. 